\title{
Analisis Matagenom Komunitas Bakteri Tempe dengan Teknik Terminal Restriction Fragment Length Polymorphism (T-RFLP)
}

\section{Metagenomic Analysis of Bacterial Diversity in Tempe using Terminal Restriction Fragment Length Polymorphism (T-RFLP) Technique}

\author{
Tati Barus ${ }^{1}$, Griselda ${ }^{1}$, Antonius Suwanto ${ }^{1,2^{*}}$, dan Tan Watumesa Agustina ${ }^{1}$ \\ ${ }^{1}$ Fakultas Teknobiologi, Universitas Katolik Indonesia Atma Jaya \\ Jl. Jenderal Sudirman No. 51, Jakarta 12930 \\ ${ }^{2}$ Departemen Biologi, Institut Pertanian Bogor, Dramaga, Bogor 16680 \\ E-mail: asuwanto@indo.net.id *Penulis untuk korespondensi
}

\begin{abstract}
Bacteria have an important role in tempe fermentation in Indonesia, aside of Rhizopus oligosporus as the dominant microbe. In this study the molecular aspect of bacterial diversity in tempe were analyzed using a fingerprinting technique, Terminal-Restriction Fragment Length Polymorphism (T-RFLP). This study was aimed to examine the diversity of bacterial community during tempe making. Bacterial diversity analysis was conducted in the first hour and the thirteenth hour after the soybean soaked while the fresh tempe was analysed at one to two hours after the fermentation ended. T-RFLP can be used to describe the diversity of bacterial community during the fermentation of tempe. T-RFLP profiles revealed the presence of 24,30 and 33 bacterial phylotypes in the first hour and the thirteenth hour after the soybean soaked as well as in fresh tempe samples. The phylotypes were dominated by unculturable bacteria group. Only several bacterial phylotypes were consistenly identified since the beginning to the end of fermentation, while most of them were only identified at certain phases along with the environmental changes (i.e: $\mathrm{pH}$ ) that occured during the fermentation process. One of the consistently identified groups belongs to Bacillus genera.
\end{abstract}

Key words: T-RFLP, metagenome, tempe, bacteria

\begin{abstract}
Abstrak
Bakteri merupakan mikroorganisme penting yang berperan pada fermentasi tempe selain Rhizopus oligosporus. Pada penelitian ini teknik molekuler, Terminal-Restriction Fragment Length Polymorphism (T-RFLP), digunakan untuk menganalisis keragaman bakteri yang digambarkan melalui kajian keragaman sidik jarinya. Tujuan penelitian adalah untuk mendapatkan informasi tentang keragaman komunitas bakteri selama proses fermentasi tempe. Analisis keragaman bakteri dikaji pada jam ke-1 dan jam ke-13 setelah perendaman kedelai serta pada tempe segar (1-2 jam setelah akhir fermentasi). T-RFLP telah berhasil menggambarkan keragaman bakteri selama proses fermentasi tempe. Berdasarkan profil $\mathrm{T}$ RFLP ditemukan secara berturut-turut sekitar 24, 30, dan 33 filotipe bakteri masing-masing pada jam ke-1 dan jam ke-13 setelah perendaman kedelai, serta pada tempe segar. Filotipe bakteri tersebut didominasi oleh kelompok yang bersifat unculturable. Beberapa filotipe bakteri tersebut ditemukan secara konsisten sejak awal hingga akhir fermentasi, namun kebanyakan di antaranya hanya ditemukan pada tahapan fermentasi tertentu. Dinamika filotipe bakteri pada setiap tahapan fermentasi mungkin terjadi karena perubahan kondisi fermentasi misalnya seperti perubahan $\mathrm{pH}$. Salah satu jenis bakteri yang ditemukan konsisten selama proses fermentasi tempe adalah kelompok Bacillus.
\end{abstract}

Kata kunci: T-RFLP, metagenome, tempe, bakteri

Diterima: 02 November 2009, disetujui: 29 April 2010 


\section{Pendahuluan}

Tempe merupakan bahan pangan penting di Indonesia sebab merupakan sumber protein yang harganya relatif murah dibandingkan dengan bahan pangan sumber protein lainnya. Tempe mengandung gizi yang baik untuk kesehatan sebab dapat mencegah anemia (Astuti, 1999) dan diare (Sudigbia, 1999), mengandung vitamin $B_{12}$ (Keuth dan Bisping, 1994) dan senyawa antioksidan (Esaki et al., 1996). Asam fitat dan tripsin yang bersifat antinutrisi ditemukan dalam jumlah yang rendah pada tempe (Shurtleff dan Aoyagi, 2001; Hong et al., 2004). Oleh sebab itu, saat ini tempe sudah populer di berbagai negara maju seperti Jepang, Belanda, dan Amerika (Karyadi, 1996).

Sejumlah laporan menyatakan bahwa bakteri berperan dalam menentukan kualitas bahan pangan yang diproduksi melalui proses fermentasi (Ampe et al., 2001; Randazo et al., 2002). Bakteri juga berperan dalam nenentukan kualitas tempe. Brevibacterium epidermidis dan Micrococus luteus berperan dalam mensintesis antioksidan pada tempe (Klus et al., 1993). Citrobacter freundii dan Klebsiella pneumoniae berperan dalam pembentukan vitamin $\mathrm{B}_{12}$ (Keuth dan Bisping, 1994). Bakteri diduga juga berperan dalam pembentukan cita rasa tempe (Barus et al., 2008). Oleh sebab itu, diperlukan analisis komunitas bakteri tempe lebih lanjut.

Sebagian besar bakteri belum dapat dikultur pada media buatan (Giraffa dan Neviani, 2001). Namun saat ini telah tersedia beberapa metode yang dapat digunakan untuk menganalisis komunitas bakteri yang bersifat menyeluruh pada habitat tertentu. Salah satu di antaranya adalah metode atau teknik Terminal Restriction Fragment Length Polymorphism (TRFLP) (Kent dan Triplett, 2002). Pada teknik TRFLP, ujung salah satu amplikon dilabel dengan senyawa berfluoresens melalui pelabelan ujung primer yang digunakan. Ukuran dan intensitas amplikon hasil pemotongan dengan enzim restriksi dideteksi profil T-RFnya. Setiap profil T-RF merupakan sidik jari bakteri tertentu dan intensitas pendarannya menggambarkan kelimpahan bakteri tersebut. Dengan demikian dapat diketahui minimal jumlah jenis bakteri dan kelimpahan relatifnya yang terdapat pada habitat tertentu.
Teknik T-RFLP telah digunakan untuk menganalisis keragaman galur Lactococcus lactis (Cansilla et al., 1992) dan Mycobacterium (Aghajani et al., 1996), serta menganalisis keragaman mikroorganisme lumpur bioreaktif dan usus rayap (Liu et al., 1997). Oleh sebab itu, teknik T-RFLP digunakan dalam penelitian ini untuk menganalisis komunitas bakteri pada tempe yang memiliki intensitas rasa pahit yang rendah (tidak pahit). Tujuan penelitian ini adalah untuk mempelajari dinamika populasi dan keragaman bakteri melalui analisis sidik jari bakteri yang berperan selama pengolahan tempe yang tidak pahit. Dari penelitian ini diharapkan ditemukan informasi profil T-RF bakteri untuk kajian lebih lanjut tentang peranan bakteri terhadap pembentukan cita rasa pada tempe.

\section{Metode Penelitian}

\section{Optimasi Ekstraksi DNA Genom}

Optimasi dilakukan dengan tujuan mendapatkan jenis kit yang paling sesuai untuk ekstraksi DNA genom bakteri tempe. Optimasi ekstraksi dilakukan secara duplo. $10 \mathrm{~g}$ contoh tempe segar dimasukkan ke dalam $90 \mathrm{~mL} \mathrm{0,85 \%}$ $\mathrm{NaCl}$ dan dilumatkan. Sebanyak $2 \mathrm{~mL}$ suspensi disentrifugasi dengan kecepatan 13000 g selama 10 menit. Supernatan dibuang dan pelet diresuspensi dengan $1 \mathrm{~mL} \quad 0,85 \% \quad \mathrm{NaCl}$. Selanjutnya, ekstraksi DNA genom dilakukan dari suspensi tempe menggunakan tiga jenis kit, yaitu Genomic DNA Purification Kit (Fermentas, Vilnius, Lithuania), QIAamp DNA Stool Mini Kit (Stool Kit; Qiagen, Valencia, California), dan FastDNA SPIN Kit for Soil (Soil Kit; Qbiogene, Solon, Ohio). Konsentrasi DNA genom yang diperoleh diukur dengan mesin GeneQuant (Amersham, Bioscience), dan selanjutnya dilakukan analisis komunitas bakteri dengan teknik T-RFLP. Kit yang memberikan hasil paling optimum yang digunakan untuk mengekstraksi DNA genom bakteri pada penelitian ini, mengikuti metode kit yang terpilih.

\section{Ekstraksi DNA Genom Bakteri untuk Analisis T-RFLP}

Ekstraksi DNA genom bakteri dilakukan pada contoh air rendaman kedelai satu jam (jam ke-1), contoh air rendaman kedelai 13 jam (jam 
ke-13), dan contoh tempe segar (1-2 jam setelah fermentasi selesai). Contoh diperoleh dari salah satu perajin tempe yang berada di wilayah Kota Bogor. Dasar pengambilan contoh dari pengrajin tersebut adalah karena tempe yang diproduksi memiliki intensitas rasa pahit yang paling rendah dari lima jenis tempe yang diuji secara sensori (Barus et al., 2008). Analisis komunitas bakteri contoh dilakukan dua periode, yaitu periode pertama dilakukan pada tahun 2008 dan periode kedua dilakukan pada awal tahun 2009.

\section{Amplifikasi Gen 16S rRNA}

Gen 16S rRNA diamplifikasi menggunakan primer 27f-FAM (5'-AGAGTTT GATCCTGGCTCAG-3') yang dilabel dengan phosphoramidite fluorochrome 6carboxylfluorescein, dan 1387r (5'-GGGCGG WGTGTACAAGGC-3') (Marchesi et al., 1998). Komposisi reaksi PCR terdiri atas $25 \mu \mathrm{l}$ GoTaq Green Mastermix (Promega, USA), $18 \mu 1$ nuclease-free water, $2 \mu \mathrm{l}$ primer $\left(5 \mathrm{pmol} \mu \mathrm{l}^{-1}\right)$, dan $3 \mu \mathrm{l}$ DNA contoh menggunakan GeneAmp PCR system 2400 (Perkin Elmer, USA). PCR sebanyak 30 siklus dilakukan pada kondisi sebagai berikut : pre-denaturasi $94^{\circ} \mathrm{C} 5$ menit, denaturasi $92^{\circ} \mathrm{C} 30$ detik, annealing $62^{\circ} \mathrm{C} 30$ detik, elongasi $72^{\circ} \mathrm{C} 30$ detik, dan paska elongasi $72^{\circ} \mathrm{C} 7$ menit. Pita DNA yang berukuran sekitar 1300 pasang basa $(\mathrm{pb})$ dipotong dan dipurifikasi menggunakan QIAquick Gel Extraction Kit (Qiagen, Valencia, California).

\section{Pemotongan Amplikon dengan Enzim Restriksi}

Amplikon hasil PCR yang telah dipurifikasi dipotong dengan enzim restriksi Bst UI (5'-CG/CG-3') dan MspI (5'-C/CGG-3') (New England Biolabs, Beverly, MA). Komposisi reaksi pemotongan masing-masing enzim terdiri atas $2 \mu \mathrm{l}$ enzim, $2 \mu \mathrm{l} 10 \mathrm{X}$ buffer restriksi, dan $16 \mu \mathrm{l}$ DNA. Pemotongan dengan enzim Bst UI diinkubasi pada suhu $60^{\circ} \mathrm{C}$ selama 16 jam, sedangkan pemotongan dengan enzim MspI diinkubasi pada suhu $37^{\circ} \mathrm{C}$ selama 16 jam. Hasil pemotongan dipurifikasi dengan metode Ethanol Precipitation (Sambrook et al., 2001).

\section{Analisis T-RFLP}

Untuk analisis T-RFLP, hasil purifikasi dari pemotongan gen $16 \mathrm{~S}$ rRNA oleh masingmasing enzim ditambah dengan $9.85 \mu 1 \mathrm{Hi} \mathrm{Di}^{\mathrm{TM}}$ dan $0.15 \mu 1$ standar internal (GeneScan ${ }^{\mathrm{TM}}$ 500 LIZ $^{\circledR}$ ). Campuran tersebut didenaturasi pada suhu $95^{\circ} \mathrm{C}$ selama 3 menit. Setelah didenaturasi, secara cepat didinginkan dalam es, selanjutnya di-running pada mesin sekuensing ABI PRISMTM 3100 Genetic Analyzer (Applied Biosystem, Foster City, California). Kondisi alat pada saat running adalah : waktu injeksi 5 menit, tegangan saat injeksi $15 \mathrm{KV}$, tegangan saat running 15 $\mathrm{KV}$, suhu $60^{\circ} \mathrm{C}$, waktu 30 menit, kekuatan laser 9.9 Mwatt. Panjang potongan terminal produk PCR yang terlabel bahan fluorosens dideterminasi menggunakan program GeneScan (Blackwood et al., 2003). Analisis data dilakukan dengan program FRAGSORT.

\section{Optimasi T-RFLP}

Tujuan optimasi T-RFLP ini mengetahui tingkat reproducibility dari metode T-RFLP yang digunakan. Optimasi analisis komunitas bakteri dengan teknik T-RFLP dilakukan terhadap contoh air rendaman kedelai jam ke-7. Gen 16S rRNA yang telah dipotong dengan $B s t \mathrm{UI}$ yang telah dipurifikasi di-running pada waktu yang berbeda untuk menguji konsistensi kesamaan profil T-RFnya.

\section{Pengkulturan dan Sekuensing Gen 16S rRNA Bakteri}

Dari masing-masing contoh dilakukan pengkuturan bakteri pada media Plate Count Agar/PCA (Oxoid). Koloni bakteri yang tumbuh dominan diidentifikasi berdasarkan sekuen gen 16S rRNAnya. Bakteri ditumbuhkan pada media Luria Broth semalam kemudian disentrifugasi pada kecepatan $10000 \mathrm{~g}$ selama 3 menit. Pelet kemudian dihomogenkan dengan $200 \mu 10.85 \%$ $\mathrm{NaCl}$, dan DNA genomnya diekstraksi menggunakan metode cethyl trimethyl ammonium bromide (CTAB). Gen 16S rRNA diamplifikasi menggunakan primer $27 \mathrm{f}$ dan 1387r. Komposisi reaksi PCR yang digunakan sama dengan prosedur PCR gen 16S rRNA dengan metode T-RFLP. Pita DNA berukuran sekitar $1300 \mathrm{pb}$ dipotong dan dipurifikasi dengan QIAquick Gel Extraction Kit (Qiagen, Valencia, California), kemudian di-sekuensing oleh Macrogen, Korea. Sekuen yang diperoleh dibandingkan dengan basis data GenBank dengan perangkat lunak BLASTN (www.ncbi.nlm.nih.gov). 


\section{Hasil dan Pembahasan}

\section{Optimasi Ekstraksi DNA Genom}

Hasil ekstraksi DNA genom bakteri tempe menggunakan tiga jenis kit (Genomic DNA Purification Kit, QIAamp DNA Stool Mini Kit, dan FastDNA SPIN kit for soil) menunjukkan bahwa penggunaan Genomic DNA Purification Kit menghasilkan konsentrasi DNA tertinggi $\left(618.75 \mathrm{ng} \mathrm{l}^{-1}\right)$, yaitu sekitar 20 kali lebih tinggi dibandingkan dengan dua jenis kit lainnya. Selain itu, Genomic DNA Purification Kit juga menghasilkan profil T-RF gen 16S rRNA yang paling beragam (Gambar 1), diikuti oleh FastDNA SPIN Kit for Soil dan QIAamp DNA Stool Mini Kit.

Hasil optimasi ini berbeda dari hasil penelitian Li et al., (2008) yang menyatakan bahwa penggunaan QIAamp DNA Stool Mini Kit untuk mengekstrak bakteri dari feses menghasilkan konsentrasi DNA yang lebih tinggi dibandingkan dengan penggunaan FastDNA SPIN Kit for Soil. Perbedaan hasil tersebut kemungkinan disebabkan karena perbedaan materi antara feses dan tempe sehingga memengaruhi kandungan konsentrasi DNA yang diperoleh. Dengan demikian, untuk kajian analisis komunitas bakteri pada suatu habitat tertentu yang berbasis DNA genom penting dilakukan optimasi ekstraksi terlebih dahulu untuk mendapatkan metode yang paling tepat.

\section{Optimasi T-RFLP}

Tujuan optimasi T-RFLP adalah untuk mengetahui apakah T-RF yang diperoleh menghasilkan profil T-RF yang sama bila dilakukan pengulangan pada contoh yang sama. Pengertian ulangan dalam hal ini dimulai dari proses amplifikasi gen 16S rRNA dengan PCR sampai determinasi profil T-RF menggunakan program GeneScan yang dilakukan pada waktu yang berbeda dari contoh yang sama. Optimasi T-RFLP dilakukan terhadap komunitas bakteri pada contoh air rendaman kedelai jam ke-7.

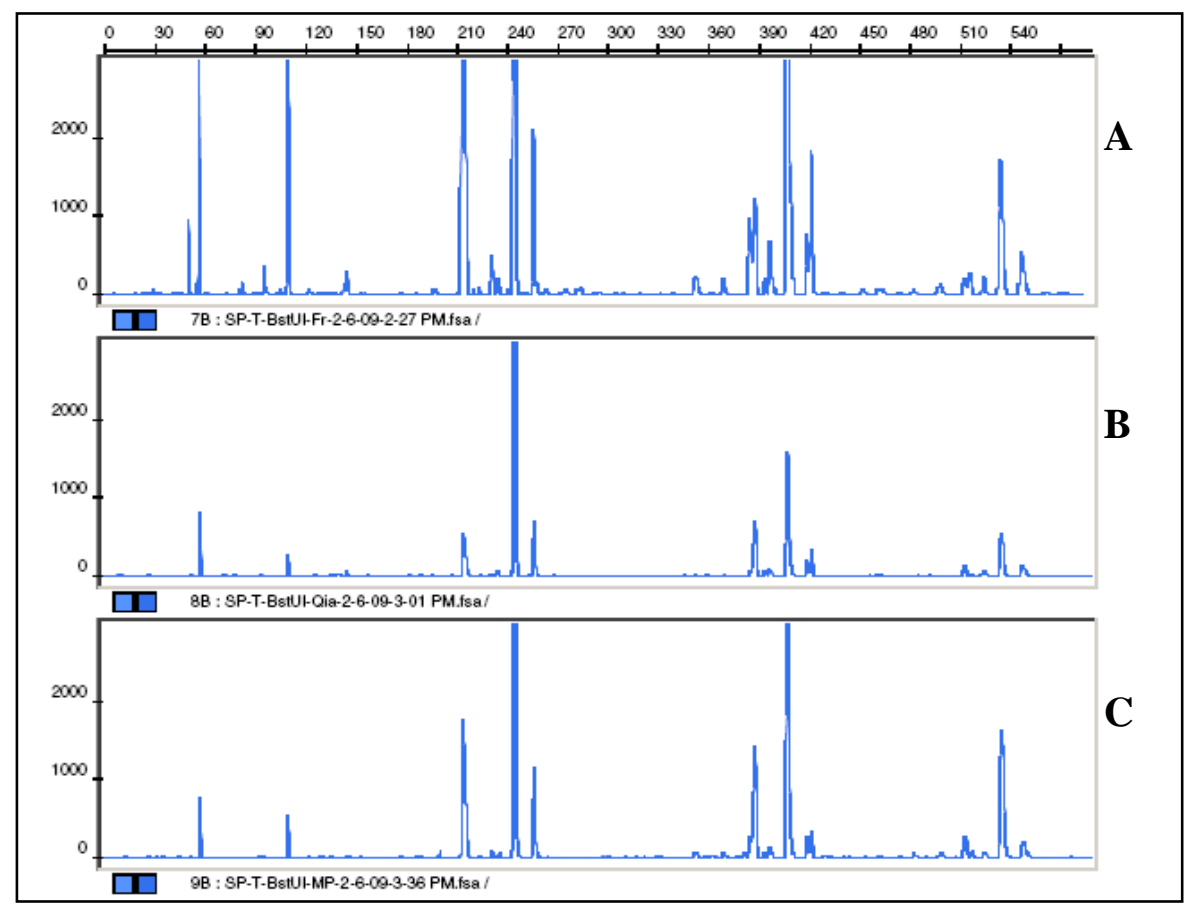

Gambar 1. Keragaman profil T-RF 16S rDNA genom bakteri tempe segar yang diekstrak menggunakan tiga jenis kit yang dipotong dengan enzim BstUI. Genomic DNA Purification Kit (A), QIAamp DNA Stool Mini Kit (B), dan FastDNA SPIN Kit for Soil (C). 
Hasil optimasi menunjukkan bahwa dari sampel yang sama tetap diperoleh profil T-RF komunitas bakteri yang sama meskipun dilakukan pengulangan (Gambar 2). Selain itu, profil T-RF yang diperoleh pada optimasi ini juga sama dengan profil T-RF yang dilakukan tiga bulan berikutnya pada contoh yang sama (Gambar 3E). Perbedaan hanya ditemukan pada tingkat intensitas T-RFnya. Hasil ini menunjukkan bahwa teknik T-RFLP bersifat reproducible dan valid digunakan untuk menganalisis komunitas bakteri pada penelitian ini. Hasil ini mendukung penelitian Li et al., (2008) dan Tiedje et al., (1999) yang menyatakan bahwa T-RFLP merupakan teknik yang dapat diulang (reproducible) dengan tingkat keakuratan tinggi sehingga efektif digunakan untuk menganalisis komunitas bakteri pada habitat tertentu. Saat ini penggunaan T-RF untuk menganalisis komunitas mikroba terus meningkat walaupun masih terus dikembangkan kemampuannya.

\section{Komposisi Komunitas Bakteri Tempe}

Analisis komunitas bakteri dengan TRFLP pada contoh air rendaman kedelai jam ke1, jam ke-13, dan tempe segar menggunakan enzim BstUI secara konsisten menghasilkan intensitas T-RF yang lebih tinggi dibandingkan dengan enzim MspI. Dengan BstUI ditemukan rata-rata 24,30 , dan 33 profil $\mathrm{T}-\mathrm{RF}$ secara berturut-turut pada air rendaman jam ke-1, jam ke-30 dan tempe segar (Tabel 1). Profil T-RF menggambarkan profil bakteri yang terdapat pada habitat tertentu. Dengan demikian ditemukan bahwa kompisisi komunitas bakteri yang terdapat pada proses pengolahan tempe sangat kompleks.

Secara keseluruhan, periode tahun 2008 dan tahun 2009, ditemukan empat T-RF yang konsisten selama pengolahan tempe (diurutkan mulai dari yang paling dominan) yaitu: $109 \mathrm{pb}$, $239 \mathrm{pb}, 220 \mathrm{pb}$, dan $396 \mathrm{pb}$ (Gambar 3) (periode 2009 tidak ditampilkan). Bila dibandingkan intensitas T-RF air rendaman antara periode tahun 2008 dan 2009, pada air rendaman jam ke1 kesamaannya sekitar $70 \%$, dan meningkat menjadi sekitar $95 \%$ pada air rendaman jam ke13.

Dari empat T-RF yang sama, T-RF yang berukuran sekitar 109 pb dan 239 pb (Gambar
3D dan 3F) jumlahnya hampir mencapai $80 \%$ dari total T-RF yang ada. Artinya bahwa kemungkinan jenis bakteri dengan tipe T-RF 109 pb dan 239 pb merupakan jenis bakteri yang telah teradaptasi dengan baik sebab kelimpahannya tetap tinggi meskipun kondisi habitat hidupnya mengalami perubahan yang drastis. Salah satu kondisi yang berubah adalah $\mathrm{pH}$, dari 6.9 pada perendaman awal turun menjadi 4.4 akhir permentasi (jam ke-13). Kedua jenis bakteri tersebut diduga berperan penting dalam menentukan kualitas contoh tempe yang dianalisis.

Pada penelitian antara periode 2009 ditemukan T-RF berukuran 116 pb (Gambar 3) pada air rendaman jam ke-1 dan jam ke-13 tetapi tidak ditemukan pada periode 2008. Selain itu, pada tempe segar juga ditemukan perbedaan kelimpahan bakteri yang sangat bervariasi bila dibandingkan antara dua periode pengamatan. Kesamaan kelimpahan bakteri pada tempe segar antara periode 2009 dan 2008 hanya mencapai sekitar $18 \%$. Perbedaan tersebut kemungkinan disebabkan oleh pengolahan tempe dilakukan pada kondisi yang tidak terkontrol, sehingga dapat menyebabkan terjadinya perbedaan jenis bakteri antar waktu pengolahan tempe.

Pada tempe segar periode 2008 ditemukan T-RF $261 \mathrm{pb}$ yang dominan, tetapi pada pengamatan periode 2009 ditemukan T-RF 239 pb yang dominan, yang juga ditemukan dominan pada air rendaman. T-RF 239 pb ini tampaknya tetap ditemukan secara konsisten pada tempe segar meskipun dengan jumlah yang bersifat fluktuatif. Perbedaan komunitas bakteri antar waktu pada proses pengolahan tempe kemungkinan berperan dalam menentukan kualitas tempe. Dengan demikian diperlukan kontrol selama proses produksi untuk mendapatkan kualitas yang konsisten.

Bakteri yang dominan pada air rendaman yang berhasil dikultur pada media PCA adalah Bacillus sp $\left(10^{8} \mathrm{cfu} / \mathrm{mL}\right)$ dengan kemiripan sebesar $99 \%$, dan Micrococcus sp $\left(10^{8} \mathrm{cfu} / \mathrm{mL}\right)$ dengan kemiripan sebesar $99 \%$ berdasarkan sekuensing gen $16 \mathrm{~S}$ rRNA. Bakteri dominan yang terdapat pada tempe segar adalah Bacillus subtilis strain ZHA9 $\left(10^{7} \mathrm{cfu} / \mathrm{mL}\right)$ dengan kemiripan sebesar $92 \%$. 


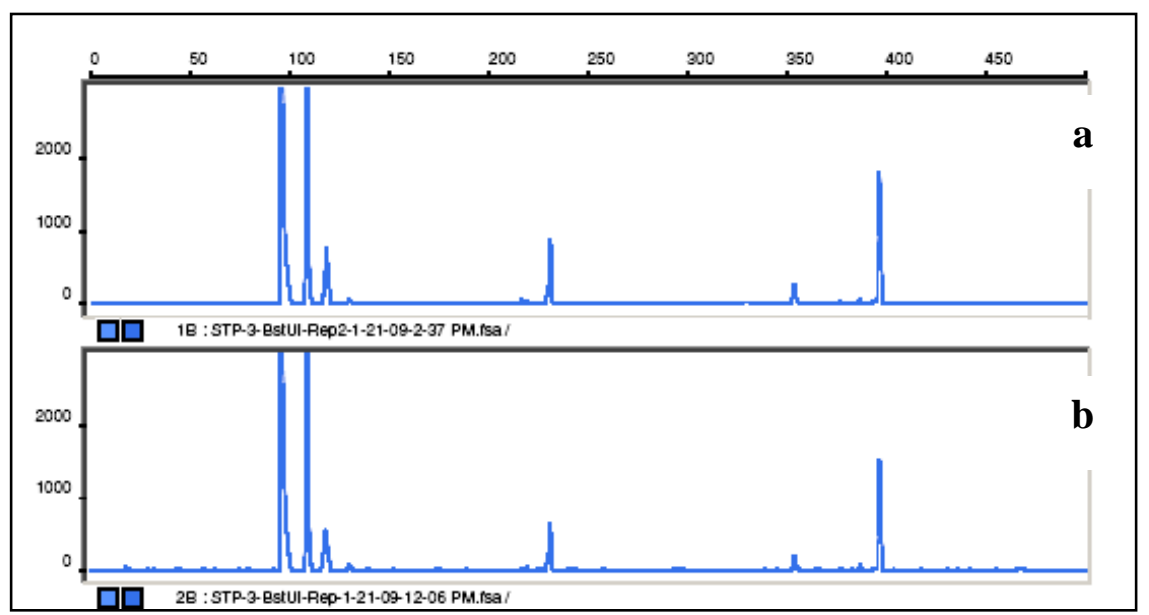

Gambar 2. Keragaman profil T-RF 16S rDNA genom bakteri air rendaman kedelai jam ke-7 yang dipotong dengan enzim BstUI. Pengulangan I (a) dan pengulangan II (b).

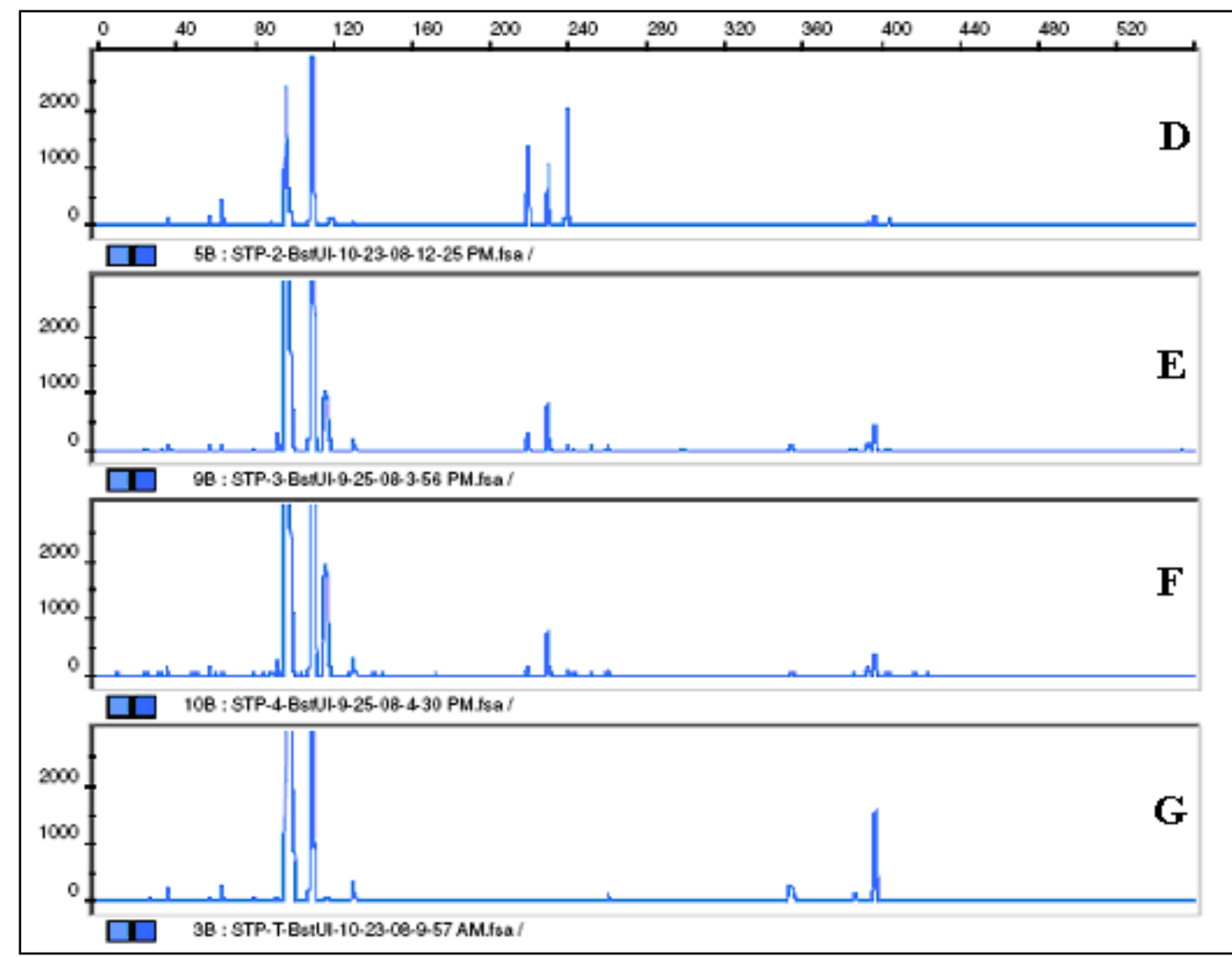

Gambar 3. Profil T-RF dari 16S rDNA hasil pemotongan dengan enzim BstUI pada analisis tahun 2009. Air rendaman jam ke-1 (D), air rendaman jam ke-7 (E), air rendaman jam ke-13 $(\mathrm{F})$, tempe segar $(\mathrm{G})$.

Tabel 1. Jumlah dan intensitas profil T-RF tempe tahun 2008 dan 2009 menggunakan enzim BstUI.

\begin{tabular}{lcccc}
\hline \hline \multirow{2}{*}{ Contoh } & \multicolumn{2}{c}{ Tahun 2008 } & \multicolumn{2}{c}{ Tahun 2009 } \\
& Jumlah Profil & Intensitas & Jumlah Profil & Intensitas \\
& T-RF & T-RF & T-RF & T-RF \\
\hline \hline Air rendaman jam ke-1 & 23 & 19771 & 25 & 25346 \\
Air rendaman jam ke-13 & 36 & 30555 & 24 & 24629 \\
Tempe segar & 35 & 32957 & 31 & 15330 \\
\hline \hline
\end{tabular}


Berdasarkan pencocokan profil T-RF yang diperoleh dengan jenis T-RF pada database (http://mica.ibest.uidaho.edu/) yang dipotong dengan enzim restriksi Bst UI dan MspI ditemukan bahwa jenis bakteri yang dominan pada contoh adalah bakteri bersifat unculturable.

Namun, T-RF yang berukuran sekitar 239 pb berdasarkan database, kemungkinan adalah kelompok Bacillus sp, dan tipe T-RF 116 adalah $\alpha$-proteobacterium atau Bacteroides sp. Berdasarkan metode pengkulturan ditemukan juga Bacillus sp. merupakan bakteri dominan pada contoh air rendaman.

Dari hasil metode pengkulturan dan analisis T-RFLP ditemukan bahwa Bacillus sp. ditemukan dalam jumlah yang relatif berlimpah selama pengolahan tempe. Keberadaan kelompok Bacillus (B. pumilus dan B. brevis) pada tempe telah dilaporkan sebelumnya (Mulyowidarso et al., 1990). Hal ini menarik untuk diteliti lebih lanjut, khususnya yang berhubungan dengan rasa pahit pada tempe. Lee et al., (2008) melaporkan bahwa galur Bacillus sp. tertentu dapat mengurangi rasa pahit pada chungkukjang (produk fermentasi kedelai asal Korea). Lebih lanjut dinyatakan bahwa chungkukjang akan memiliki rasa yang lebih pahit bila tidak diinokulasi dengan Bacillus sp.

Bacillus sp. yang ditemukan pada tempe yang dianalisis memiliki aktivitas proteolitik, sehingga memungkinkan bakteri ini untuk dapat memecah peptida pendek yang terbentuk menjadi ukuran yang lebih kecil lagi, sehingga rasa pahit pada tempe dapat berkurang. Penelitian untuk membuktikan hipotesis tersebut dan penelitian tentang peran Bacillus sp. dalam menentukan kualitas tempe, sedang berlangsung di laboratorium kami.

\section{Simpulan dan Saran}

\section{Simpulan}

Komunitas bakteri yang terdapat selama proses pengolahan tempe bersifat sangat kompleks, baik jenis dan jumlahnya. Bacillus sp. ditemukan secara konsisten dalam proses pengolahan tempe. Selama proses pengolahan terjadi dinamika populasi bakteri seiring dengan perubahan kondisi proses fermentasi tempe.

\section{Saran}

Perlu dilakukan penelitian lebih lanjut tentang peran Bacillus terhadap kualitas nutrisi dan cita rasa tempe.

\section{Ucapan Terima Kasih}

Penelitian ini dibiayai oleh Direktorat Penelitian dan Pengabdian pada Masyarakat melalui Hibah Kompetitif Penelitian Sesuai Prioritas Nasional Tahun 2009. Sesuai dengan Surat Perjanjian Pelaksanaan Hibah Penelitian Tahun Anggaran 2009 Nomor: 025/SP2H/PP/ DP2M/IV/2009. Oleh sebab itu diucapkan terima kasih kepada DP2M DIKTI yang telah mengadakan Hibah tersebut.

\section{Daftar Pustaka}

Aghajani, E.A., Jones, K., Holtzman, A., Aronson, T., Glover, N., Boian, M., Froman, S. dan Brunk, C.F. 1996. Molecular Technique for Rapid Identification of Mycobacteria. J. Clinical Microbiol, 1996: 98-102.

Ampe, F., Sirvent, A. dan Zakhia, N. 2001. Dynamic of Microbial Community Responsible for Traditional Sour Cassava Starch Fermentation Studied by Denaturing Gradient Gel Electrophoresis and Quantitative rRNA Hybridization. Int J. Food Microbiol., 65: 45-54.

Astuti, M. 1999. Iron Availability of Tempe and Uses in Iron Deficiency Anemia. In: Agranoff, J., Sutrisno, N. (Eds). The Complete Handbook of Tempe: The Unique Fermented Soybean of Indonesia. The American Soybean Association

Barus, T., Suwanto, A., Wahyudi, A.T. dan Wijaya, H. 2008. Role of Bacteria in Tempe Bitter Taste Formation: Microbiological and Molecular Biological Analysis Based on 16S rRNA Gene. Microbiol Indonesia, 2 (1): 17-21.

Blackwood, C.B., Marsh, T., Kim, S.H. dan Paul, E.A. 2003. Terminal Restriction Fragment Length Polymorphism Data Analysis for Quantitative Comparison of Microbial Communities. Appl Environ Microbiol., 69: 926-932.

Cansilla, M.R., Powell, I.B., Hillier, A.J. dan Davidson, B.E. 1992. Rapid Genomic Fingerprinting of Lactococcus lactis Strains by Arbitrary Primed Polymerase Chain Reaction with 32P and Fluorescent Labels. Appl. Environ Microbiol., 58: $1772-1775$. 
Esaki, H.H., Onozaki, S., Kawakish dan Osawa, T. 1996. New Antioxidant Isolation from Tempe. $J$. Agric Food Chem., 44: 696-700.

Giraffa, G. dan Neviani. 2001. DNA-based, Culture Independent Strategies for Evaluating Microbial Communities in Food-associated Ecosystem. $J$. Food Microbiol., 67: 19-34.

Hong, K.J., Lee, C.H. dan Kim, S.W. 2004. Aspergillus oryzae GB-107 Fermentation Improves Nutritional Quality of Food Soybeans and Feed Soybean Meals. J. Med Food., 7 (4): 430-5.

Karyadi, D. 1996. Perkembangan Tempe di Lima Benua Di dalam: Bunga Rampai Tempe Indonesia. Penerbit Yayasan Tempe Indonesia.

Kent, A.D. dan Triplett, E.W. 2002. Microbial Communities and Their Interaction in Soil and Rhizosphere Ecosystems. Ann Rev Micribiol. 56: $211-236$

Keuth, S. dan Bisping, B. 1994. Vitamin B $_{12}$ Production by Citrobacter freundii or Klebsiella pneumoniae During Tempeh Fermentation and Proof of Enterotoxin Absence by PCR. J. Appl. Environ Microbiol., 60: 1495-1499.

Klus, K., Borger-Papendorf, G. dan Barz, W. 1993. Formation of $6,7,4$ Trihydroxyisoflavone (Factor 2) from Soybean Seed Isoflavones by Bacteria Isolated from Tempe. J. Phytochem, 34: 979-981.

Lee, M.Y., No, H.K., Kim, S.D. dan Prinyawiwatkul, W. 2008. Quality of Chungkukjangs Prepared with Various Bacillus strains. Int J. Food Sci., 42: 587-592.

Li, F., Hullar, M.A.J. dan Lampe, J.W. 2008. Optimization of Terminal Restriction Length Polymorphism (T-RFLP) of Human Gut Microbiota. $J$. Microbiol Methods., 68: 303-311.

Liu, W., Marsh, T.L., Cheng, H. dan Forney, L.J. 1997. Characterization of Microbial Diversity by
Determining Terminal Restriction Fragment Length Polymorphisms of Genes Encoding 16S rRNA. Appl. Environ Microbiol., 63: 4516-4522.

Marchesi, J.R., Sato, T., Weightman, A.J., Martin, T.A., Fry, J.C., Hiom, S.J. dan Wade, W.G. 1998. Design and Evaluation of Useful BacteriumSpecific PCR Primers that Amplify Genes Coding for Bacterial 16S rRNA. Appl. Environ. Microbiol., 64: 795-799.

Mulyowidarso, R.K., Fleet, R.K. dan Buckle, K.A. 1989. The Microbial Ecology of Soybean Soaking for Tempe Production. International J. of Food Microbiol., 8: 35-46.

Randazzo, C.L., Toriani, S., Akkermans, D.A.D.L., de Vos, W.M. dan Vaughan, E.E. 2002. Diversity, Dynamics and Activity of Bacterial Communities during Production of an Artisanal Sisilian Cheese as Evaluated by $16 \mathrm{~S}$ rRNA Analysis. Appl. Environ Microbiol., 68: 1882-1892.

Sambrook, J. dan Russel, D.W. 2001. Moleculer Cloning, A Laboratory Manual. Ed. Ke-3. Cold Spring Harbor Laboratory Pres. New York.

Shurtleff, W. dan Aoyagi, A. 2001. The book of Tempe: A Cultured Soyfood. Ten Speed Press, Berkeley, CA.

Sudigbia, I. 1999. Tempe in the Management of Infant Diarrhea in Indonesia. In: Agranoff, J. \& Sutrisno, N. (Eds.). The Complete Handbook of Tempe: The Unique Fermented Soybean of Indonesia. The American Soybean Association.

Tiedje, J.M., Asumsing-Brempong, S., Nusslein, K., Marsh, T.L. dan Flynn, S.J. 1999. Opening the Black Box of Soil Microbial Diversity. Appl. Soil Ecol., 13: 109-122. 